\title{
Pump Dosing Unit
}

National Cancer Institute

\section{Source}

National Cancer Institute. Pump Dosing Unit. NCI Thesaurus. Code C111984.

A dosing unit equal to the amount of active ing redient(s) contained in one actuation of a pumping device. 